\title{
SOCIODEMOGRAPHIC CONDITIONS AND PATTERNS OF CRACK USE AMONG WOMEN ${ }^{1}$
}

\author{
Vania Dias Cruz², Michele Mandagará de Oliveira ${ }^{3}$, Leandro Barbosa de Pinho4, Valéria Cristina Christello \\ Coimbra ${ }^{5}$, Luciane Prado Kantorski ${ }^{6}$, Jeane Freitas de Oliveira ${ }^{7}$
}

\footnotetext{
${ }^{1}$ Extracted from the dissertation - "Vivências de mulheres que consomem crack em Pelotas-RS", presented to the Graduate Program in Nursing, Universidade Federal de Pelotas (UFPel), 2012.

${ }^{2}$ Doctoral student. Graduate Program in Nursing, Universidade Federal de Rio Grande. Rio Grande, Rio Grande do Sul, Brazil. E-mail: vania_diascruz@hotmail.com

${ }^{3}$ Ph.D. in Public Health Nursing. Professor, Department of Nursing, UFPel. Pelotas, Rio Grande do Sul, Brazil. E-mail: mandagara@hotmail.com

${ }^{4}$ Ph.D. in Psychiatric Nursing. Professor, Department of Nursing, Universidade Federal do Rio Grande do Sul. Porto Alegre, Rio Grande do Sul, Brazil. E-mail: lbpinho@uol.com.br

${ }^{5}$ Ph.D. in Psychiatric Nursing. Professor, Department of Nursing, UFPel. Pelotas, Rio Grande do Sul, Brazil. E-mail: valeriacoimbra@hotmail.com

${ }^{6}$ Ph.D. in Nursing. Professor, Department of Nursing, UFPel. Pelotas, Rio Grande do Sul, Brazil. E-mail: kantorski@uol.com.br

${ }^{7}$ Ph.D. in Public Health. Professor, School of Nursing, Universidade Federal da Bahia. Salvador, Bahia, Brazil. E-mail: jeanefreitas@ ig.com.br
}

\begin{abstract}
The aim of this study was to characterize the sociodemographic conditions and patterns of crack use among women. A descriptive-exploratory study with a qualitative approach was performed in January 2012, using semi-structured interviews with 16 women who use or used crack, and were enrolled in the Damage Reduction Strategy of the municipality of Pelotas, in the state of Rio Grande do Sul, Brazil. Data were analyzed using the thematic content analysis. A group of young women was identified with low levels of education and income, which perform informal labor activities and have at least one child. The pattern of crack use among these women was identified as the "binge" type, interfering with daily activities, and characterizing the group of women as abusive users. The pattern of crack use among the women, and its relation to issues of gender, pointed to the production of new insertions and discourses, bringing into question pre-defined behaviors in society.
\end{abstract}

DESCRIPTORS: Drug users. Crack cocaine. Women. Gender identity.

\section{CONDIÇÕES SOCIODEMOGRÁFICAS E PADRÕES DE CONSUMO DE CRACK ENTRE MULHERES}

RESUMO: O objetivo deste estudo foi caracterizar as condições sociodemográficas e os padrões de consumo de crack entre mulheres. Realizou-se um estudo exploratório-descritivo, de abordagem qualitativa, por meio de entrevista semiestruturada com 16 mulheres que consomem ou consumiam crack cadastradas na Estratégia de Redução de Danos de Pelotas-RS, no mês de janeiro de 2012. Para a análise dos resultados, utilizou-se a análise de conteúdo, na modalidade análise temática. Identificou-se um grupo de mulheres jovens, com baixa escolaridade e renda, exercendo atividades ocupacionais informais e com pelo menos um filho. O consumo de crack era do tipo "binge" e interferia nas atividades diárias preexistentes, caracterizando o grupo de mulheres como usuárias abusivas. A partir do padrão de consumo de crack entre as mulheres e sua relação com questões de gênero, constatou-se a produção de novas inserções e discursos, pondo em discussão os comportamentos predefinidos na sociedade.

DESCRITORES: Usuários de drogas. Crack. Mulheres. Identidade de gênero.

\section{CONDICIONES SOCIODEMOGRÁFICAS Y PATRONES DE CONSUMO DE CRACK ENTRE MUJERES}

RESUMEN: El objetivo de este estudio fue caracterizar las condiciones sociodemográficas y los patrones de consumo de crack entre mujeres. Se realizó un estudio exploratorio y descriptivo de abordaje cualitativo, por medio de una entrevista semiestructurada con 16 mujeres que consumían crack, registradas en la Estrategia de Reducción de Daños de Pelotas-RS, en el mes de enero de 2012. Para el análisis de los resultados se utilizó el análisis de contenido, en la modalidad análisis temático. Se identificó un grupo de mujeres jóvenes, con baja escolaridad y renta, ejerciendo actividades ocupacionales informales y con por lo menos 1 hijo. El consumo de crack era del tipo "binge" e interfería en las actividades diarias pre-existentes, caracterizando el grupo de mujeres como usuarias abusivas. El patrón de consumo de crack entre las mujeres y su relación con cuestiones de género constató la producción de nuevas inserciones y discursos poniendo en discusión los comportamientos predefinidos en la sociedad.

DESCRIPTORES: Consumidores de drogas. Cocaína crack. Mujeres. Identidad de Género. 


\section{INTRODUCTION}

In light of the increasing use of crack in Brazil, the media has associated the use of psychoactive substances (PAS) to complex social problems such as violence and crime in its advertisements and news reports, and thus influenced the social imagination with very little concern for truly understanding the phenomenon. Influenced by the sensationalism of news reports and slogans such as "crack kills," the population clamors for state action, and contributes to the consolidation of stereotypes about users of PAS. ${ }^{1-2}$

The existence of patterns of use of PAS has been recognized since $1984,{ }^{3}$ and proven in some studies. ${ }^{1-4}$ The first study concerning differentiated drug use, conducted with users of marijuana, psychedelics and opiates (heroin), revealed that a significant portion of people are able to maintain balance between consumption, minimum health care and independence from the substance. ${ }^{3}$

Three factors are pointed to as determinants for defining the pattern of use of PAS, these being: the substance, i.e., the pharmacological action, including dosage and the manner in which it is used (intravenous, snorted, smoked, etc.); the set, which corresponds to the state of the person at the time of use (personality, expectations before use); and the setting, which is the influence of the physical and social environment where use occurs (other people, place, cultural meanings attributed to use). ${ }^{3}$

Based on these factors, the pattern of use of PAS is characterized as controlled or abusive. The first has low costs to society and does not cause social harm to the person who uses it, being characterized by informal rules such as defining the optimal amount of PAS to be consumed, without it interfering with daily activities; ${ }^{4}$ to define physical and social environments that provide safety; to identify the effects of the substance, proposing standards of behavior and maintaining their social activities, moving away from marginalization. ${ }^{3}$ The second is defined by uncontrolled and dysfunctional use, in which the person is unable to maintain control over use, and his or her thinking is focused only on the next use of the PAS, so that sleep, food, affection, sense of responsibility and survival lose significance. ${ }^{3-4}$

The use of PAS is higher among the male population, yet a decrease in the proportion of men and women who use these substances is being recorded, due to the broad access that women have to these drugs today, and especially the lifestyle changes in the lives of women in the last century. ${ }^{5}$ In Brazil, data from the $1^{\text {st }}$ household survey on the use of psychotropic drugs, conducted with a sample of $41.3 \%$ of the total population, $57 \%$ of which are women, confirm this scenario, in which the use of benzodiazepines and amphetamines was shown to be three times higher among women in comparison to men. ${ }^{6}$

The scientific literature offers little data on the use of crack and other illicit PAS among women, which impedes the development of accurate estimates on use and implications surrounding this issue. The difficulty in identifying these women may be associated with shame, fear of judgment/ bias, lifestyle and social isolation that many experience, or even lack of technical skills of health care professionals to identify the signs and symptoms of a woman who uses PAS. 5,7-8

Publications addressing the use of crack and other PAS indicate that men and women show different patterns of use. With regard to experimentation, women generally begin use through a partner or a family member, whereas men begin through friends. The possible influence of men on women to start and maintain use of PAS is broadly cited in the specialized literature. ${ }^{5,7-8}$ There are reports of women who become abusive users because they consume the substance in order to keep their partners' company, who become their primary suppliers, thus avoiding exposure to dealing points and the community. ${ }^{7-8}$ Moreover, the motivation to use PAS among women tends to occur because of dissatisfaction, symptoms of depression, feelings of social isolation and lack of life projects, whereas with men it is often related to external problems such as professional, financial and criminal difficulties. ${ }^{7}$

When intervening in the use of PAS, it is essential to take into account the structural elements of gender relations that permeate our society, such as roles and functions determined for men and women. Adopting a perspective of gender will allow to understand the pattern of crack use among women, and how their socialization occurs, in which the population condemns or encourages certain social practices, such as using crack in secret, and not seeking treatment for fear of being identified. ${ }^{9}$

Hence, gender relations ${ }^{10}$ and theory on patterns of drug use ${ }^{3}$ were used as the theoreticalmethodological framework in this study. Since 
prehistoric times, different PAS have been used for purposes that range from playful, mystical and religious to merely obtaining pleasure. Therefore, depending on the purpose of use, the effects of the drugs are given, i.e., there is another way to think and discuss [the issue] that is not only limited to the drug as responsible for the behavior of individuals, but rather to the person inserted into its social context from the perspective of psychological, sociological and cultural factors that shape motivations, experiences and behaviors, and are capable of characterizing the person who uses drugs as controlled or abusive. ${ }^{3}$

In this sense, patterns of crack use by women are associated with their experiences in the social context, and influenced by structural elements of power relations, including gender. The perspective of gender is increasingly recognized as a powerful approach to recognize the impact of drug use in society by individuals or groups, being understood by systems of signs and symbols that highlight the power relations between the sexes, and influence patterns of use of PAS. ${ }^{9}$

Given the considerations presented above, the aim of this paper was to characterize the sociodemographic conditions and patterns of crack use among women. This study is justified by the need to know the patterns of crack use from the perspective of gender, understanding the phenomenon as a construction that produces social meanings and should be inserted into the research and everyday practices of health care professionals, thereby contributing to comprehensive care appropriate to the specificities of women who use crack. ${ }^{9}$ Thus, the study focused on constructing styles of crack use among women, characterizing the participants as "abusive" and "controlled" 3 and relating this to the perspective of gender. ${ }^{10}$

\section{METHODOLOGY}

The data presented were the result of a qualitative, exploratory-descriptive study ${ }^{11}$ linked to the research project entitled, "Profile of crack users and use patterns," funded by CNPq through bidding MCT/CNPq 41/2010.

The study participants included 16 women who use/ used crack, were registered in the Damage Reduction Strategy (DRS), recommended by the team of Damage Reducing Agents (DRAs), and also met the following inclusion criteria: being a woman, over 18 years of age, using or having used crack cocaine for a minimum period of one year, and being registered in the DRS of Pelotas.

Data were collected through the DRA of Pelotas-RS, which is a sector of the Municipal Health Department (MHD), and connected to the Management of the Program for Sexually Transmitted Diseases, being understood and organized within the Damage Reduction Program (DRP). The DRS is located in the MHD of the City of Pelotas, and is composed of one coordinator, one nurse and six DRAs, which seek to undertake work aimed at direct care for users in the five major areas of the city: Areal, Fragata, Zona Norte, Centro and São Gonçalo.

Data collection was performed in January 2012 using a semi-structured interview that included questions related to the sociodemographic conditions of the women who use crack, their experiences using crack, and characterization of a typical crack use scene. Voice recorders were used for greater reliability of the interviews. The participants' anonymity was ensured by labeling the interviews with the letter I (for "interviewed") and the interview order number. The interviews were conducted during fieldwork by DRAs in different neighborhoods of Pelotas, providing for data collection in the context of the individuals. Thirteen women were interviewed in their homes, two in a crack house, and one in her workplace (car security) in the city center. Each interview lasted about 45 minutes.

The development of the study complied with the principles of resolution no. 196/96 of the National Health Council (Regulatory Guidelines and Standards for Research involving Humans). The project was approved by the Research Ethics Committee of the College of Nursing of the Federal University of Pelotas, under protocol no. 301/2011.

The contents of the interviews were transcribed verbatim and subjected to repeated readings, following the steps of thematic content analysis, ${ }^{12}$ from the perspective of gender theory. ${ }^{10}$ Thus, data were analyzed in three distinct phases: pre-analysis, material exploration and processing of data and interpretation.

During pre-analysis, the data obtained in the interviews were ordered by transcription, reading, material organization and reexamination of initial hypotheses and study objectives. In the exploration of the material, classification was developed through exhaustive reading of the data obtained, identifying the main ideas and empirical catego- 
ries, resuming the literature review on women who use crack, and constituting a 'corpus' that was regrouped according to the following categories: "Sociodemographic characterization of women who use crack" and "Characterization of the pattern of crack use"; the treatment of the results obtained and the interpretation were marked by the time at which the researchers proposed the inferences and performed interpretations according to gender relations and patterns of use of PAS. ${ }^{12}$

\section{RESULTS}

\section{Sociodemographic characteristics of women who use crack}

Table 1 shows the sociodemographic characteristics of the study group participants (n =16) by age, skin color, education, marital status, occupation, number of children and nominal monthly income.

Table 1 - Sociodemographic characteristics of women who use crack. Pelotas, Rio Grande do Sul, 2012

\begin{tabular}{|c|c|c|c|c|c|c|c|}
\hline ID & Age & $\begin{array}{l}\text { Skin } \\
\text { color }\end{array}$ & Level of Education & Marital status & Occupation & $\begin{array}{l}\text { No. of } \\
\text { children }\end{array}$ & Income R\$ \\
\hline I1 & 46 & Black & $\begin{array}{l}\text { Incomplete primary } \\
\text { school }\end{array}$ & With partner & $\begin{array}{l}\text { Informal } \\
\text { activity }\end{array}$ & 3 & 305.00 \\
\hline $\mathrm{I} 2$ & 20 & Brown & $\begin{array}{l}\text { Incomplete primary } \\
\text { school }\end{array}$ & Single & $\begin{array}{l}\text { Informal } \\
\text { activity }\end{array}$ & 0 & 50.00 \\
\hline I3 & 30 & White & $\begin{array}{l}\text { Incomplete primary } \\
\text { school }\end{array}$ & Single & $\begin{array}{l}\text { Informal } \\
\text { activity }\end{array}$ & 6 & 650.00 \\
\hline I4 & 37 & Brown & $\begin{array}{l}\text { Incomplete high } \\
\text { school }\end{array}$ & Divorced & $\begin{array}{l}\text { Informal } \\
\text { activity }\end{array}$ & 4 & $2,000.00$ \\
\hline I5 & 32 & Brown & $\begin{array}{l}\text { Incomplete primary } \\
\text { school }\end{array}$ & With partner & Unemployed & 2 & 00.00 \\
\hline I6 & 31 & White & $\begin{array}{l}\text { Complete high } \\
\text { school }\end{array}$ & With partner & $\begin{array}{l}\text { Informal } \\
\text { activity }\end{array}$ & 4 & 400.00 \\
\hline I7 & 35 & Brown & $\begin{array}{l}\text { Incomplete primary } \\
\text { school }\end{array}$ & Single & $\begin{array}{l}\text { Informal } \\
\text { activity }\end{array}$ & 2 & 200.00 \\
\hline I8 & 42 & White & $\begin{array}{l}\text { Incomplete primary } \\
\text { school }\end{array}$ & Divorced & $\begin{array}{l}\text { Informal } \\
\text { activity }\end{array}$ & 1 & 450.00 \\
\hline I9 & 51 & White & $\begin{array}{l}\text { Incomplete primary } \\
\text { school }\end{array}$ & Divorced & $\begin{array}{l}\text { Informal } \\
\text { activity }\end{array}$ & 2 & 200,00 \\
\hline I10 & 28 & White & $\begin{array}{l}\text { Incomplete primary } \\
\text { school }\end{array}$ & With partner & $\begin{array}{l}\text { Informal } \\
\text { activity }\end{array}$ & 3 & 200.00 \\
\hline I11 & 25 & Black & $\begin{array}{l}\text { Incomplete high } \\
\text { school }\end{array}$ & With partner & $\begin{array}{l}\text { Informal } \\
\text { activity }\end{array}$ & 2 & 700.00 \\
\hline I12 & 30 & Black & $\begin{array}{l}\text { Incomplete primary } \\
\text { school }\end{array}$ & With partner & Unemployed & 4 & 00.00 \\
\hline I13 & 19 & Brown & $\begin{array}{l}\text { Incomplete primary } \\
\text { school }\end{array}$ & With partner & Unemployed & 1 & 00.00 \\
\hline I14 & 29 & Black & $\begin{array}{l}\text { Incomplete primary } \\
\text { school }\end{array}$ & Married & $\begin{array}{l}\text { Informal } \\
\text { activity }\end{array}$ & 6 & 228.00 \\
\hline I15 & 37 & White & $\begin{array}{l}\text { Incomplete primary } \\
\text { school }\end{array}$ & Single & $\begin{array}{l}\text { Informal } \\
\text { activity }\end{array}$ & 2 & 450.00 \\
\hline I16 & 48 & White & $\begin{array}{l}\text { Incomplete primary } \\
\text { school }\end{array}$ & Widowed & $\begin{array}{l}\text { Informal } \\
\text { activity }\end{array}$ & 4 & 48.00 \\
\hline
\end{tabular}


Regarding occupational characteristics, according to the participants, 13 practiced informal activities. The most frequently cited occupations by the women were housework, including work as a cleaner, caretaker of children and elderly companion, followed by prostitution.

I'm a nanny, cook and housekeeper, all in the same place [...] (I3); I'm a hustler (I7); Maid. I retired from sex work a long time ago (19); Cleaner and prostitute, it depends on the day, time and place (I11); Domestic worker, I take care of an elderly lady (I14).

Of the total number of participants, only one reported not having children. Of the remaining number with children, 13 reported not living with them.

I have six children and three live with me. I gave them away because of the addiction; I could not care for them, I gave them to a relative, Child Services took the other from me [...] (I3); [...] so as not to abandon them, and so that they don't have really crazy contact with me, I preferred to give the four to my ex-husband's mother [...] but the abandonment that was for protection has become a thing against me [...]. She is drugged out, she is prostituting herself, so she can't take care of the children, so I chose to leave them in peace and not bother about the return in order not to fight [...] (I6); [...] I have 4 [...] because of the rock, they live with my relatives (I12).

\section{Characterization of the pattern of crack use}

This category was subdivided into the following subcategories: physical and social context of use; management of crack use: doses and lessons; and motivations and expectations for use. These three factors interfere and are responsible for defining the pattern of controlled or abusive use of crack among the participants.

\section{Physical and social context of use}

The study participants reported using crack in private places out of public view, opting to keep their use secret or just in the presence of a few people, in order to have safe and positive experiences.

I only smoked in the house of other users I knew, people I trusted [...] (I5); I smoke where there's no one watching me [...] I try to hide, if they see me I don't know (I7); I like to smoke in the house alone [...] I smoke on the street very rarely (I11).

Feelings of persecution, fear of violence and anxiety are some of the reasons that lead users to limit their company at the time of use, enjoying crack alone or with someone they trust, such as their partner.

For shooting up, I liked shooting up alone, to smoke my rock too, because I had some paranoia, I saw bugs, I hid, I saw the police. So I didn't like to use drugs with anyone, I liked to use alone, I didn't trust anyone, I was always afraid that someone would catch me, mistreat me or rob me (I3); With the father of my daughter and friends (I5); I use it with him [partner] (I11); It was just me and my husband, it was rare to have a friend, and when one was there, it was just one, because I thought: 'Not all crack users act the same way,' so I was afraid because we change, and you can't say no. Someone is going to come in here to use drugs and get violent, I thought (I14).

\section{Management of crack use: doses and lessons}

The women reported smoking crack in an intense, continuous and repetitive manner, followed by an abrupt stop to their use for a few days.

One rock is $R \$ 5.00$. One gram should be about eight rocks, I use about 15 rocks per day, everyday, I use almost all day, all night, it depends on how much there is [...] but we control it, we don't go out killing anyone, you control yourself [...] (I6); I use three, four, five rocks, there are days when I don't use, but if I have the urge I smoke day and night [...] while I'm working [formal] I don't use anything, only on Sunday I drink some beer and look [...] I've stopped before for four years [...] If you steal you go to jail, so I have to do this [prostitution] [...] and I need to smoke to give up my body (I7); I use every day, five or six rocks per day [...] I stop for a day or two, but that's the maximum (I8).

Crack use only to promote sociability and fun was also reported.

I use two at the most, I used yesterday and today I didn't sleep, so today I don't want to [...] his friends [partner] who bring the drug, a lot of times, they come and I go out [...] I don't use every day, only if the urge hits me [...] it's just a little fun [...] I've gone for two months without smoking, but I started again to have fun [...] I'm not going to spend my money on it, I only use if my friends give it to me (I13).

Furthermore, there were women who participated in this study who claimed they had not used crack for more than six months: [...] it's been a long time, I think about two years [...] (I1); [...] It's going to be a year and three months since I've smoked (I2); [...] I've been clean for six months and three days (I3); [...] it's been two years since I've smoked [...] (I15).

The participants reported that crack use does not always happen in isolation, i.e., it is usually 
used in conjunction with other PAS, which intensify and/or mitigate certain physical effects. This situation revealed lessons learned in the crack culture, and some patterns of behavior to be followed.

I drink cachaça and smoke tobacco together (I10); [...] I used crack with alcohol, because I don't like weed. I had to drink pure cachaça [...] when I didn't have cachaça I drank pure alcohol, if I didn't, I'd get that horrible feeling of fear, of persecution [...] (I14); [...] then when there's no more nervousness from the crack, to relax and to eat, I smoke weed (I16).

\section{Motivations and expectations for use}

The participants reported having started to use crack due to the influence of a person in their social circle, usually a man.

I was 34 years old. About three of my colleagues offered it to me. He said: try it, it will be good, it will ease your troubles [...] I had someone [former partner] who encouraged me, and we used compulsively. But this one [current partner], since he doesn't use, sometimes he criticizes me, represses me, but he gives me money to buy it [...] (I4).

The participants cited several motivations for initiating and continuing crack use, the most frequently cited being emotional, health and family problems, situations of loss, partnership with a crack user, distraction, a method for coping with sadness or to celebrate happy times, and because they simply enjoyed using.

What led me to use drugs was prostitution, I'm certain of this, and then the fact of me being HIV positive, and also because I had to hand over my son, at that moment when I gave him up [Guardianship Council] I gave up a little bit of me. It was very difficult and I had a husband who was a user and drug dealer (I3); It depends, sometimes I use because I'm really happy, sometimes because I'm really sad, it's all an excuse to use. I use because I want to, I like the drug I use, honestly, I don't think about stopping (I11); From watching him [partner] smoke I get the urge, it's just a little fun, a vice, I smoke, I talk, I tidy things (I13).

\section{DISCUSSION}

The women interviewed for this study who self-identified themselves as black or brown (9), were between 19 and 48 years old (15), had incomplete primary education (13), income below one minimum monthly wage (about US\$330.00) (14), worked informally (13) or were unemployed (3), had a partner (7) and had at least one child (15).
These findings corroborate the results of another study ${ }^{13}$ regarding level of education and professional activity; however, there were differences in skin color and marital status, and single, white women predominated in the study cited.

Some of the participants were in disadvantaged social and economic situations. Although 13 of them work, low level of education combined with the low professional qualifications results in the exercise of informal activities such as: house cleaner, caregivers of the elderly and children, and prostitutes. Because they do not require technical training, these activities offer low pay, but they are sufficient to maintain the consumption for the social standards of these women.

Fifteen of the participants have at least one child, however, these children often do not live with their mother. Due to the effects that the abusive use of crack produces in people, sometimes care of children is usurped by need for the drug. In this process, some lost their children to the child protection agency, others because they understood the risks and consequences that crack use posed to their children, and hoping to protect them, chose to leave them under the care of relatives.

In the Brazilian culture in general, only women engage in childcare, whereas the father is considered just one element of the support network, when he participates in childcare at all. This cultural construction is reinforced by the way health care services are organized and direct their practices, focusing on pregnancy and childcare as the exclusive responsibility of women, which contributes to female submission and the return of antiquated values attributed to women. ${ }^{14}$ Thus, some symbols on the female role historically constructed and explained and interpreted by religious, educational and cultural doctrines, for example, caring for children, remain intact to the present, as if these configurations were a natural part of being a woman. ${ }^{10}$

In opposition to this line of thinking, some women believed that the act of delivering their child to a family member constitutes an act of protection and care. Having knowledge of the risks and negative consequences that use can cause on the lives of the children, since hallucinations caused by drugs can affect the ability of the mothers to make appropriate decisions, and consequently the effective care of the child, they preferred to keep their children far away.

In regard to the physical and social context of consumption, the participants reported using 
crack indoors with a restricted group of friends or with people they trust, showing concern about their safety and also with concealing their use. A similar situation was found in a study with 30 crack users in the city of São Paulo, in which participants preferred to use crack alone, usually indoors, for example, in their homes, because of frequent fights in groups and increased aggressiveness caused by the drug. ${ }^{15}$

Women who use PAS suffer social stigma, as they present a typically male behavior, and are judged as being promiscuous, immoral and incapable of taking care of their family and children. As a result, many use in secret, making them more vulnerable to risk social and health situations, such as violence, prostitution, problems with pregnancy, responsibility for their children, and treatment for use of PAS. ${ }^{7,16}$

The study participants used the crack in binges, characterized by continuous days of consumption, followed by a few days break, usually due to running out of the substance or physical exhaustion. ${ }^{17}$ They tend to manifest changes in their basic needs, such as: not eating and not sleeping during the binge episode, and symptoms of malaise, exhaustion, tremors, vomiting and dizziness. ${ }^{17}$ Another factor that contributes to women becoming abusive crack users is that acquiring the drug is easier for women than men, because generally their partners become their main suppliers. ${ }^{16}$

The act of using crack only for increased sociability and fun, in limited quantities and times, was identified in this study, with the interviewee considered a controlled crack user, because the PAS is not a priority in her life. The setting ${ }^{3}$ is presented in the statement by I13, when she stated that she only used crack when her husband gave it to her, noting that the availability of the PAS encourages use. Thus, there are people who continue to use the drug because they do not have negative experiences resulting from such use, and because this practice is natural in the context in which they live. ${ }^{17}$

Furthermore, at the time of the interviews, some women defined themselves as former crack users because it had been more than six months since they had used. The decision to stop using crack is influenced by several factors, including: drug cravings, the emotional state of the person, undergoing treatment and some environmental stimuli. There are studies that show the tendency of individuals to employ strategies to regulate their consumption and even stop using crack, such as re- moval from the social context in which they used; structuring of daily activities and leisure; diversion of attention and thoughts to other practices, and moderation in the use of other substances which serve as "triggers" for crack use, ${ }^{4,18}$ thus demonstrating power and control over their lives.

The ability of a person who uses crack to be under control of their life is often denied by health care professionals and society which, influenced by the media and news reports that use pejorative terms and emotional emphasis when addressing the use of PAS, which include expressions such as "it is an abyss," believe that every person who uses crack is a drug addict. ${ }^{1}$

In order to ease the withdrawal symptoms of crack cocaine and the effects of its use, some strategies such as using crack with alcohol, marijuana and/or tobacco were identified in this study. Alcohol consumption after crack use is a method to inhibit or decrease the resulting effect of paranoia. Marijuana, in addition to reducing the undesirable effects of crack use, reduces the craving, which would allow, in the long term, socio-occupational reintegration of the user. ${ }^{4}$ The combination of smoking crack and tobacco can be justified mainly by the possibility of using it in public places, and the need of using the ashes for combustion of the rock. ${ }^{19}$

Contrary to common sense beliefs, crack users in general develop knowledge about the substance, which they share between them, such as informal rules and controls for self-regulation, such as the quantity and combinations of PAS to be used. ${ }^{1}$ In this context, the women, when they acquire knowledge to mitigate the effects of crack, gain power and space in the group, occupying a position of prestige, and becoming role models for the other users that still do not have such power or ability. ${ }^{1}$ Thus, the power to control the effects of the crack can be understood in this study as a mechanism to enhance, transform and reverse positions and situations in the scenario of the drugs. ${ }^{9}$

The women interviewed reported that they started to use crack because a friend or acquaintance had offered it to them. When considering the difference between men and women in obtaining drugs, one study on the risk behaviors of female crack users found that $90 \%$ of the women, when they tried crack for the first time, got the drug from a "friend," and only $69 \%$ of men obtained it in the same manner. ${ }^{19}$ Confronting these findings, other studies have identified that initial drug use by young, adult women is frequently associated with 
the presence of loving relationships with partners or family members who were also users..$^{5,7}$

The participants mentioned several reasons for maintaining crack use. Their statements showed that crack use by some women is a choice, a lifestyle, and not considered a problem; on the contrary, it was a solution to face life challenges, such as prostitution. Nevertheless, others said that they used crack in an attempt to escape the solitude of their problems and losses. These results corroborate one study with young people who use alcohol and other drugs in a student residence hall of the University of São Paulo, in which all participants reported using drugs to endure hardship, to forget problems and poorly resolved situations. ${ }^{20}$

The reports also showed some influence by partners who also use crack, in the maintenance of the women's use, due to the fact that the women follow their partner's lead in use, as they receive money from him to buy the drug, or so that they do not need to expose themselves to risky situations to acquire the crack, because the partner assumes responsibility for this process. The motivation of the women to initiate and maintain frequent use of illicit PAS is related to having a romantic relationship with a partner who is also a user. ${ }^{7}$ Emotional dependence and the need to feel accepted by the partner lead some women to "follow" their lead, thus taking the first step to abusive use of the drug. ${ }^{5}$

\section{CONCLUSION}

This study identified the sociodemographic characteristics and patterns of crack use among the women studied, revealing the influence of gender relations on the behaviors experienced by the women, and harm reduction strategies used to alleviate the negative effects of crack use, which deserve consideration for health care.

The pattern of crack use among women, and their relation to gender issues, was noted in the production of new insertions and discourses among the people, putting in discussion predefined limits in society such as masculinity/ femininity, and showing that these values are currently in crisis and in a process of change.

The perspective of gender to analyze the women who use crack allowed for understanding the existence of hierarchy, inequality and disobedience, in which there are multiple tensions of negotiation, cooperation, conflict and alliances, capable of reversing the position of users within the group.
Given the above, there is a need to be concerned not only with the abuse of crack, but also the risk factors to quality of life and treating people as individuals, because men and women who use crack have different needs and consequences, and thus it is essential to build a reference framework for action that includes both the individual and the social.

The limits of analysis of the study include its methodological design: the inability to generalize the results due to the limited number of participants, and the valuation of certain aspects over others by choosing a theoretical framework to guide the study.

The study's contribution to nursing and health care involves the formation of public policies on drug abuse. It is also important to consider the fact of analyzing damage reduction strategies in daily health care work. Nurses must know the different social groups and their specific needs, in order to effectively promote practices that encourage health.

\section{REFERENCES}

1. Malheiro LSB. Rituais sociais e o acesso a atenção básica em saúde entre pessoas que usam crack no centro histórico de Salvador: uma pesquisa com fins a intervenção social em redução de danos [trabalho de conclusão de curso]. Salvador (BA): UFBA; 2010.

2. Spricigo, JS, Carraro, TE, Cartana, MHF, Reibnitz, KS. Atenção ao usuário de drogas - Um espaço para o enfermeiro. Texto Contexto Enferm. 2004 Abr-Jun; 13(2):296-302.

3. Zinberg N. Drug, set and setting, New Haven (US): Yale University Press, 1984.

4. Oliveira LG, Nappo SA. Caracterização da cultura de crack na cidade de São Paulo: padrão de uso controlado. Rev Saude Pública. 2008 Ago; 42(4):664-71.

5. Pardo LS. Género y drogas: guía informativa: drogas y género: Plan de Atención Integral a la Salud de la Mujer de Galicia. Galacia (TR): Subdirección Xeral de Saúde Mental e Drogodependencias; 2009.

6. Carlini EA, Galduróz JC, Noto AR, Nappo AS. I levantamento domiciliar sobre o uso de drogas psicotrópicas no Brasil: estudo envolvendo as 107 maiores cidades do país. São Paulo (SP): UNIFESP; 2002.

7. Severine D. The specificities of female drug addiction. [online] 2004 Ago [acesso 2012 Dec 10]; [about 03 p.]. Disaponível em: http://www. drugtext.org/Gender-issues/the-specifities-offemale-drug-addiction.html

8. Oliveira JF, McCallum CA, Costa HOlG. Social representations of community health agents 
Cruz VD, Oliveira MM, Pinho LB, Coimbra VCC, Kantorski LP, Oliveira JF

regarding drug use. Rev Esc Enferm USP. 2010 Set; 44(3): 611-8.

9. Moraes M. Gênero e usos de drogas: porque é importante articular esses temas? In: Moraes $\mathrm{M}$, Castro R, Petuco D. Gênero e drogas: contribuições para uma atenção integral a saúde. Recife (PE): Instituto PAPAI/Gema/UFPE; 2011.

10. Scott, JW. Gênero: uma categoria útil de análise histórica. Educ Real. 1990; 16(2):5-22.

11. Cruz VD. Vivências de mulheres que consomem crack em Pelotas-RS [dissertação]. Pelotas (RS): Universidade Federal de Pelotas. Programa de PósGraduação em Enfermagem; 2012.

12. Minayo MCS. O desafio do conhecimento: pesquisa qualitativa em saúde. São Paulo (SP): Hucitec, 2010.

13. Elbreder MF, Laranjeira R, Siqueira MM, Barbosa DA. Perfil de mulheres usuárias de álcool em ambulatório especializado em dependência química. J Bras Psiquiatr. 2008 Jan; 57(1):9-15.

14. Cabral FB, Oliveira DLLC. Women's vulnerability in the puerperium from the view of Family Health Teams: emphasis on generational aspects and adolescence. Rev Esc Enferm USP. 2010 Jun; 44(2): 368-75.
15. Ribeiro LA, Sanchez ZM, Nappo SA. Estratégias desenvolvidas por usuários de crack para lidar com os riscos decorrentes do consumo da droga. J Bras Psiquiatr. 2010 Ago; 59(3):210-8.

16. Oliveira JF, Paiva MS. Vulnerabilidade de mulheres usuárias de drogas ao hiv/aids em uma perspectiva de gênero. Esc Anna Nery. 2007 Dez; 11(4):625-31.

17. Raupp L, Adorno RCF. Jovens em situação de rua e usos de crack: um estudo etnográfico em duas cidades. RBAC. 2011; (4):52-67.

18. Chaves TV, Sanchez ZM, Ribeiro LA, Nappo SA. Fissura por crack: comportamentos e estratégias de controle de usuários e ex-usuários. Rev Saúde Pública. 2011 Dez; 45(6):1168-75.

19. Zeni TC, Araújo RB. Relação entre o craving por tabaco e o craving por crack em pacientes internados para desintoxicação. J Bras Psiquiatr. 2011 Jan; 60(1):28-33.

20. Zalaf MRR, Fonseca RMGS. Abusing alcohol and other drugs in students' dormitories: knowing it in order to face it. Rev Esc Enferm USP. 2009 Mar; 43(1):132-8. 